\title{
The responsiveness of Bachelor of Elementary Education curriculum: An illuminative evaluation
}

\author{
Michael B. Cahapay \\ College of Education, Mindanao State University, Philippines
}

\begin{tabular}{l} 
Article Info \\
\hline Article history: \\
Received Apr 6, 2020 \\
Revised Jun 18, 2020 \\
Accepted Jul 18, 2020 \\
\hline
\end{tabular}

\section{Keywords:}

Curriculum development Illuminative evaluation Responsiveness

Teacher education

\begin{abstract}
As higher education institutions are pressured to evaluate the responsiveness of their curriculum programs, there is a challenge of first order to define responsiveness. This challenge, however, is compounded by the paucity of a tested evaluation model that addresses it. Thus, this paper aimed to evaluate the responsiveness of the Bachelor of Elementary Education curriculum by attempting the applicability of the model called "illuminative evaluation." Following the stages and components within the social anthropological framework of the model, multiple methods such as interviews, document reviews, and surveys were employed. The main data analysis technique used was the thematic analysis. The results revealed that illuminative evaluation contextually defined the concept of responsiveness and it effectively uncovered concealed aspects that indicate discrepancies within the curriculum. Thus, given these research outcomes, this work contributes new knowledge to the tradition of evaluation theory and provides practical evidence for the improvement of the curriculum under evaluation. The recommendations are offered at the end of the study.
\end{abstract}

This is an open access article under the CC BY-SA license.

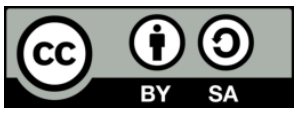

\section{Corresponding Author:}

Michael B. Cahapay,

College of Education,

Mindanao State University,

Fatima, General Santos City, 9500 South Cotabato, Philippines.

Email: mbcahapay@up.edu.ph

\section{INTRODUCTION}

Higher education institutions continually deal with pressures coming from different directions. This condition often raises a concern about the responsiveness of their curriculum programs. They are expected to increase their responsiveness with regard to the changing contexts by restructuring their curriculum programs to meet the needs and interests of society [1]. With that expectation, universities and colleges are urged to reconsider the responsiveness of their curriculum programs.

This goal of responsiveness is reflected in the demand for higher education institutions in the Philippines. Through the Memorandum Order No. 2 Series of 2011, the Commission on Higher Education [2] made the curriculum development in the tertiary level minimally prescriptive. This approach allowed colleges and universities to exercise freedom in determining their curriculum programs based on their needs. This effort to develop a responsive curriculum is also mirrored in the mandate of Mindanao State University (MSU), General Santos City (GSC). As an institution of higher learning situated in a culturally diverse region, it is expected to offer responsive programs to promote the development of its community [3]. Such a purpose is further entrenched at the level of the Bachelor of Elementary Education (BEEd) program. Its instruction expresses an aspiration to produce elementary school teachers equipped with a philosophy of teaching that is responsive to the changing social environment. 
These circumstances have turned the attention of most higher education institutions to evaluate if their curriculum programs meet the responsiveness that is being demanded. However, a primary task of first order to this endeavor is the need to define responsiveness. The concept of responsiveness depends on the purpose, place, and time [4], is a complex debate [5] and has multiple facets [6]. For this reason, a myriad of definitions of responsiveness in education abounds [7-18]. Thus, if there is no single discourse nor grand narrative of the concept of responsiveness [9], then curriculum evaluation requires an exhaustive approach that works from the ground. Considering the evaluation needs of the curriculum under study, however, there appears to be an absence of a tested evaluation approach that intends to reach judgments about the responsiveness of a curriculum from the grassroots level.

The traditional and technical approach to evaluation has always been focused on the extent to which the stated goal of a program is achieved. But due to its heavy focus on the goal, evaluation has also been prone to privileging the overt aspect of the program. It does not account for the covert aspects of the program which may otherwise function in pervasive ways. As a result of this discontent, scholars have turned to a more naturalistic approach of evaluation. Such an approach views each program as different, intending to understand its complexities, and responding to its members from the ground [19-22].

An evaluation model that adopts a naturalistic approach was advocated by Parlett and Hamilton [22] called "illuminative evaluation." This model uses two basic components: instructional system or "the formalized plans and statements which relate to a particular teaching arrangement" [23] and learning milieu defined as "the social, psychological, and material environment in which students and teachers work together" [23]. It focuses attention on the discovery of discrepancies between the instructional system and the learning milieu [24]. It also views that there is no absolute reality [25]. This framework appears to address the problem of the current curriculum under evaluation.

A review of past evaluation studies within the domain of education [26-45] shows that illuminative evaluation has been mostly employed to examine the implementation of a course, innovation, or program. Following the approach of illuminative evaluation, the educational intents are established from the sources representing the instructional system, and the issues are progressively focused on the implementation in learning milieu. This typical application of illuminative evaluation can be reconsidered in this study to uncover the concept of responsiveness as desired and actualized in the curriculum.

Through the enlightenment of the complexities of responsiveness using the illuminative evaluation approach, this study will present pieces of evidence to theory, practice, and research. The result will generate theoretical knowledge about the applicability of the evaluation model in a curriculum where features are obscured. It will also provide practical information for the teachers who are involved in the improvement of the current curriculum under study. Lastly, it will serve as a research benchmark for innovations in the use of the illuminative evaluation model.

Considering the circumstances established in this paper, the purpose of this work is to evaluate the responsiveness of the BEEd curriculum using the illuminative evaluation model. Specifically, it answered the following questions: 1) What is responsiveness as desired in the instructional system and as actualized in the learning milieu? 2) What discrepancies emerge when themes of responsiveness they are placed in a broader comparative perspective? 3) Is illuminative evaluation appropriate in defining responsiveness, thus uncovering the covert aspects within the curriculum components?

\section{RESEARCH METHOD}

\subsection{Research design}

This research entailed an evaluation research design that is directed toward making judgments about the merit or worth of a program [46]. It further employed a model known as illuminative evaluation [22]. This model is guided by the analysis of the two components of the instructional system and learning milieu. It also follows the three developmental stages of investigation, inquiry, and explanation. These components and stages work within the social anthropological framework [28] and are adopted to guide the data collection process of this study.

\subsection{Sampling technique}

The sample of this study was selected through purposeful sampling, a technique in which the researcher carefully chooses the participants considering the intention of the study with the expectation that every participant will be able to furnish relevant data to the study [47]. This sampling design meets the needs of this study in which participants with a degree of involvement in the curriculum were selected to provide information to the study. The sample consisted of six college faculty members that included the dean, chairperson, and professors who participate in the continuous development of the BEEd instructional system. It also consisted of eight BEEd students who have considerable direct experience of the BEEd learning milieu. They were selected regardless of age, gender, section, and academic standing. 


\subsection{Data sources}

This work used multiple sources of data that included interviews and documents as well as surveys following the principles of illuminative evaluation [28]. To uncover the latent meaning of responsiveness, the researcher primarily conducted interviews and document reviews. The interviews and document reviews revolved around key questions designed to generate answers regarding what responsive instructional system and learning milieu mean. Moreover, survey questionnaires were developed in the process of this study. They consisted of statements about responsiveness structured on a rating scale. They were used to validate if the concepts captured in the interviews and document reviews were accurate and consistent.

\subsection{Data analysis}

The utterances recorded from interviews and information gleaned from document reviews were categorized to generate themes of responsiveness. The data were subjected to the process of thematic analysis. Thematic analysis is a technique that employs scrutiny of utterances or information, interpreting them into constructs and concepts. These constructs and concepts are then grouped into themes, simplifying the results and at the same time structuring the data to answer the research questions [48].

\section{RESULTS AND DISCUSSION}

\subsection{Responsiveness as desired in the instructional system}

This study initially gathered a continuous record of information to determine how responsiveness is desired in the BEEd instructional system. Responsiveness was studied in the first stage through the perspectives of the college dean, department chairperson, and faculty members who are continually involved in the development of the curriculum program. Moreover, relevant documents such as operations manual, memorandum orders, program of study, course catalog, and instructional plans were examined to further view how responsiveness is desired in the written intentions of the program. The utterances and information gathered in this stage were subjected to thematic analysis. The analysis of constructs and concepts generated the following themes. These themes define responsiveness as desired in the instructional system.

Theme 1: A responsive instructional system considers regulatory, accreditation, licensure, and industry factors that influence it. The instructional system seeks to address the influences of important external factors that shape its instructional system. These important external factors consist of CHED as the highest regulatory body in higher education, Accrediting Agency of Chartered Colleges and Universities of the Philippines (AACCUP) as an accrediting agency, Licensure Examination for Teachers (LET) as a licensing program for graduates, and Department of Education (DepEd) as the main industry for graduates.

Theme 2: A responsive instructional system adheres to the philosophy of the institution. As a part of a greater institution, the instructional system aspires to achieve the mandates of the College of Education and MSU GSC. Its three department objectives on instruction, research, and extension are hoped to attain the goals of the College of Education and ultimately the philosophy of MSU GSC as a whole.

Theme 3: A responsive instructional system connects theory to practice through instruction, research, and extension. The instructional system has both theory and practice components which the program intends to connect through the functions of instruction, research, and extension. The different professional education courses are expected not only to introduce students to the foundation but also to integrate research and extension that create avenues for application.

Theme 4: A responsive instructional system caters to the psychological, cultural, and economic backgrounds of the students. Acknowledging the diversity of the immediate community that it serves, the BEEd instructional system desires to demonstrate respect for individualities in different aspects. It desires to pursue an atmosphere that recognizes the uniqueness of its students when it comes to their learning capabilities, cultural experiences, and financial circumstances.

Theme 5: A responsive instructional system holistically develops the students in terms of all learning domains. The instructional system strives to produce teachers who are well rounded. As such, it wants to develop its students in all three domains of cognitive, psychomotor, and affective. The graduates are expected to demonstrate not only knowledge but also the skill in and values that are needed to become effective teachers in the field.

Theme 6: A responsive instructional system assists students to learn at maximum through the use of alternative methods and open discussions. One of the intentions of the instructional system is to provide means that promote maximum learning of its students. This intent is believed to be attained when alternative methods and open discussions are practiced in the classroom to encourage all students to learn. 


\subsection{Responsiveness as actualized in the learning milieu}

Furthermore, this research progressively focused to determine how responsiveness is actualized in the BEEd learning milieu. Hence, responsiveness in the second stage was studied through the perspectives of the students who have direct experience in the teaching and learning process. Relevant documents such as sample instructional plans, instructional materials, assessment tools, and student outputs were also examined to further look into how responsiveness is actualized in the learning milieu of the program. The utterances and information gathered were subjected to the same process of thematic analysis in the previous stage. The analysis of constructs and concepts produced the following themes. These themes define responsiveness as desired in the learning milieu.

Theme 1: A responsive learning milieu considers licensure and industry factors that influence it. The DepEd and LET are the two main factors for which influences were actualized in the learning milieu. The influence of LET shaped mainly the assessment practices such as traditional testing approaches that measure higher-order thinking skills of the students, thus preparing them to take the licensure examination. The influence of DepEd, on the other hand, was evident in the integration of competencies required for public school teachers into the courses learned by the students.

Theme 2: A responsive learning milieu adheres to the philosophy of the institution. The course outcomes appeared to be aligned to the stated objectives of the BEEd Department, the goals of the College of Education, and the philosophy of MSU GSC as a whole. It was observed that course outcomes sufficiently spelled out instruction, research, and extension which are the core functions of the BEEd Department, College of Education, and MSU GSC.

Theme 3: A responsive learning milieu connects theory to the practice through instruction, research, and extension. The connection between theory and practice of education was attained through instruction, research, and extension. The instruction delivered allowed for balanced teaching of theory and practice of education. These were further realized as students engaged in research and extension.

Theme 4: A responsive learning milieu caters to the psychological, cultural, and personal backgrounds of the students. Students expressed they experienced a high degree of respect in terms of how they are treated in the class. They disclosed that their learning capabilities, cultural experiences, and personal perspectives were being considered by the teachers in the process.

Theme 5: A responsive learning milieu holistically develops the students in terms of all domains of learning. The pieces of evidence show how students were required to demonstrate their learning gains through an array of assessment strategies. The students showcased their mastery through different tests, essays, journals, and performances requiring integration of knowledge, skills, and values, indicating attainment of the desire for total student development.

Theme 6: A responsive learning milieu assists students to learn at maximum through the use of alternative methods, instructional materials, open discussions, and vernacular translations. Students claimed that they were provided with different means to learn better. They suggested that the use of alternative methods, instructional materials, and vernacular translations assisted them in their learning.

\subsection{Responsiveness as desired in the instructional system and as actualized in the learning milieu}

Finally, this study organized the themes of responsiveness in a broader comparative perspective. These themes were carefully compared in this final stage to reach judgments as regards the discrepancies between the instructional system and learning milieu. The comparison is shown in Table 1.

Table 1. Comparison of themes of responsiveness as desired and actualized

\begin{tabular}{cll}
\hline Theme & Responsiveness as Desired & Responsiveness as Actualized \\
\hline 1 & $\begin{array}{l}\text { Considers regulatory, accreditation, licensure and industry } \\
\text { factors that influence it }\end{array}$ & $\begin{array}{l}\text { Considers licensure and industry factors that influence it } \\
\text { Adheres to the philosophy of the institution as a whole } \\
\text { Connects theory to practice through instruction, research, } \\
\text { and extension }\end{array}$ \\
$\begin{array}{l}\text { Caters to the psychological, cultural, and economic } \\
\text { backgrounds of the students }\end{array}$ & $\begin{array}{l}\text { Adheres to the philosophy of the institution as a whole } \\
\text { Connects theory to the practice through instruction, research, } \\
\text { and extension } \\
\text { Caters to the psychological, cultural and personal } \\
\text { backgrounds of the students } \\
\text { learning } \\
\text { Assists students to learn at maximum through the use of } \\
\text { alternative methods and open discussions }\end{array}$ & $\begin{array}{l}\text { Holistically develops the students in terms of all domains of } \\
\text { learning } \\
\text { Assists students to learn at maximum through the use of } \\
\text { alternative methods, instructional materials, open discussions, } \\
\text { and vernacular translations }\end{array}$ \\
\hline
\end{tabular}

Based on the comparison of the themes of responsiveness between the two components, the following results emerged. The points of agreement and discrepancy are discussed. 
A general agreement of key themes of responsiveness in both components is evident in Theme 2 , Theme 3, and Theme 5. Both the instructional system and instructional milieu adhere to the philosophy of the whole institution; connect theory to practice through instruction, research, and extension; and holistically develop the students in terms of all learning domains. It implies that these key themes are both desired and actualized. An institution has a philosophy expressed in its mission, vision, and values that are entrenched at many different levels. The responsive curriculum should align with the mission, vision, and values of its institution [1, 49]. Moreover, discipline or field has its view of knowledge and process. With that assumption, a responsive curriculum in the discipline or field of education should connect theory to practice $[18,50]$ as teaching is based on sound theories and is essentially a set of practices. The total development of the students must also be a focus of responsiveness. Hence, the curriculum should be more than just the transfer of knowledge and skills; it should holistically involve qualities that may be hard to measure but are essential such as critical thinking, resourcefulness, and creativity $[10,51]$. The points of agreement found in this evaluation research present evidence of coherence within the curriculum.

On the other hand, a discrepancy is evident in Theme 1. It was revealed that the instructional system ideally aspires to address the regulatory, accreditation, licensure, and industry factors that influence it. However, it appeared in the learning milieu that only the influences of licensure and industry factors were markedly considered. This difference in the emphasis of certain factors in the two components does not necessarily point to a negative gap; it rather reflects the multifaceted aspects to consider for a curriculum to be responsive. It is undeniable, however, that the relationship between the economy and the need for higher education institutions to be responsive is the central concern in this issue. Higher education institutions are pressured to highlight skills development in their curriculum to produce competitive graduates that meet the skills required in the market $[9,12]$. This could be the reason why regulatory, accreditation, licensure, and industry factors were highly considered in the present instructional system under study. It should be noted, however, that there is a need to reflect the influences of these factors to the learning milieu to achieve the overall purposes of the curriculum in relation to the external demands.

Moreover, two minor but interesting discrepancies can be observed as well in Theme 4. First, the instructional system considers the economic background of the students. The teachers desire to account for the diverse financial conditions of the students in planning the course requirements. However, it appeared not overtly practiced in the learning milieu. Second, the learning milieu considers the personal background of the students. The students feel a level of respect when their ideas are recognized by the teachers. However, it seemed not overtly aspired in the instructional system. As a whole, the theme of responsiveness as completely considering the different backgrounds of the students stresses the role of higher education in promoting harmony as a ground of sustainable human development. It is the principal responsibility of higher education institutions to promote social competence to deal with differences. Higher education institutions need to expand their role of intellectual pluralism amidst the differences [17, 52]. Considering this aspect of a responsive curriculum, it is important to overtly bring together within the current curriculum the desires and practices related to diversity, so that a sense of match between the two components will be attained.

Lastly, a discrepancy is further noted in Theme 6. It was underpinned that both components generally assist students to optimally learn. However, the approaches to arrive at this end are different. While the instructional system promotes alternative methods and open discussions, the learning milieu makes use of instructional materials and vernacular translations on top of the other two. It is said that ensuring a responsive curriculum in terms of what approaches best assist students to learn at maximum raises a great challenge. All students are disadvantaged, but some struggle more than the others. A curriculum can be said to be responsive if it teaches the students in ways that they learn. Thus, a responsive curriculum in this sense entails the development of approaches that account for the learning characteristics of the students $[1,6]$. As regards the discrepancy noted in this theme, a general resolution can be presented. There is an imperative to continually level off what approaches teachers ideally know and what approaches students practically need. These approaches should then be coherently brought to the repertory of the desired and actualized components of the curriculum.

Overall, the six themes uncovered in this study align in part to the hierarchical model of responsiveness. The model identifies four general levels of responsiveness as economic responsiveness, cultural responsiveness, disciplinary responsiveness, and learning responsiveness. There are debates as to the importance of each level of responsiveness. However, it should be noted that the hierarchy in this model is tentative. The levels should not be equated to the importance and there is a necessary cohesive association among the levels $[1,6]$. The themes identified in this study each fall to one of the levels in the hierarchical model of responsiveness. However, it should be noted that the themes do not necessarily portray a hierarchical chain, but are seen as essential pieces in the overall concept of responsiveness. 


\section{CONCLUSION}

Based on the results of this research, the concept of responsiveness in the context of the curriculum under evaluation can be fully defined as one that considers regulatory, accreditation, licensure and industry factors that influence it; adheres to the philosophy of the whole institution; connects theory to practice through instruction, research, and extension; caters the personal, psychological, cultural, and economic backgrounds of the students; holistically develops the students in terms of all learning domains; and assists students to learn at maximum through the use of alternative methods, instructional materials, open discussions, and vernacular translations.

This work adopting the illuminative model is significant in the tradition of evaluation. It exhaustively defined the concept of responsiveness as desired and actualized in the context of the curriculum under the study. Such a task may have been otherwise a difficult one using other evaluation models. Considering this result, this inquiry adds knowledge to evaluation theory as to the applicability of illuminative evaluation in situations where a concept such as responsiveness is only implied.

This article also presents essential guidance in the current work of curriculum evaluation. It effectively uncovered the different themes of responsiveness in one component that are important but absent in another component. Such a process illuminated the areas of discrepancy within the curriculum. With this result, this paper provides a cogent basis for what discrepancies within the curriculum should be reconciled, thus promoting a sense of overall consistency between the components.

Considering also the constraint encountered in the process of this research, one primary method in the naturalistic approach of evaluation is observation. It should be emphasized that the use of observation is a hallmark of naturalistic evaluation. Thus, further illuminative evaluation using observation in combination with other methods should be endeavored to reveal more concealed aspects of the curriculum.

\section{ACKNOWLEDGMENTS}

The researcher would like to express his gratitude to the faculty members and BEEd students of the College of Education, Mindanao State University, General Santos City.

\section{REFERENCES}

[1] N. Ogude and M. Oosthuizen, "The challenge of curriculum responsiveness in South African higher education," Council of Higher Education, Pretoria, 2005. [Online]. Available: https://www.che.ac.za/ media_and_publicationche-events-presentations/challenge-curriculum-resposniveness-south-african

[2] Commission on Higher Education, "Revised guidelines in the formulation of CHED policies, standards and guidelines of academic programs," Official memorandum, Philippines, 2011.

[3] The Manual for Curriculum Revision and Development and Offering of New Program, Mindanao State University, Marawi, 2002.

[4] M. Gallagher, "Encouraging university responsiveness: Student-focussed incentives in Australian higher education," Commonwealth Department of Education, Science and Training, Brisbane, 2001.

[5] M. Singh, "Re-inserting the "public good' into higher education," Kagisano CHE Higher Education Discussion Series, vol. 1, pp. 8-18, 2001.

[6] I. Moll, "Curriculum responsiveness: The anatomy of a concept," in Curriculum Responsiveness Case Studies in Higher Education, H. Griesel, Ed. South African Universities' Vice-Chancellors' Association: Pretoria, 2004

[7] C.E. Edwards, "Exploring students' and teachers' perceptions of the cultural responsiveness in three programs for African American students," Ph.D. dissertation, New York University, New York, 2010.

[8] D. Ferdinand, "Workforce education and development curriculum responsiveness to culturally and internationally diverse graduate students: a mixed methods study," Ph.D. dissertation, Southern Illinois University, 2009.

[9] H. Griesel, "Universities and the world of work: A case study on graduate attributes," Council on Higher Education, Relations between Higher Education and the Labour Market 2002, 2002. [Online]. Available: http://www.che.ac.za/documents/d000037/Colloquium_Report.pdf

[10] S. Jones, "Managing curriculum development: A case study of enterprise in higher education," in Higher Education and Work, J. Brennan, M. Kogan \& U. Teichler, Eds. Jessica Kingsley: London, 1996.

[11] R. Khattar and C.A. Wein, "Illness and the concept of aesthetic responsiveness in early childhood education," Journal of the Canadian Association for Curriculum Studies, vol. 10, no. 2, pp. 70-91, 2012.

[12] M.W. Makgoba, Conceptions of a transformed university, Council on Higher Education, Pretoria, 2004

[13] K. McIntosh, et al, "Perceived cultural responsiveness and effectiveness of a speech and language program for indigenous preschool students," Multicultural Learning and Teaching, vol. 8, no. 1, pp. 47-64, 2013.

[14] J. Muller, "Responsivity and innovation in higher education," Centre for Higher Education and Training, 2001.

[15] D. Geduld and H. Sathorar, "Humanising pedagogy: An alternative approach to curriculum design that enhances rigour in a B.Ed. programme," Perspectives in Education, vol. 34, no. 1, pp. 41-52, 2016. 
[16] M.R. Reece, “An examination of principals' curriculum and instructional design practices in relationship to cultural responsiveness and high performance schools: a quantitative correlational study," Ph.D. dissertation, Keiser University, 2016.

[17] C.G. Schneider, "From diversity to engaging difference: A framework for the higher education curriculum," in Knowledge, Identity and Curriculum Transformation in South Africa, N. Cloete, J. Muller, M.W. Makgoba and D. Ekong, Eds. Maskew Miller Longman: Cape Town, 1997.

[18] L. Slonimsky and Y. Shalem, "Pedagogic responsiveness for academic depth," in Curriculum responsiveness case studies in higher education, H. Griesel, Ed. South African Universities Vice-Chancellors' Association, 2004.

[19] E.R. House, Evaluating with validity. Beverly Hills: Sage Publications, 1980.

[20] B.D. Kerr, "A responsive evaluation of a graduate distance education course offering: Education 6104 foundations of program evaluation," M.A. Thesis, Memorial University of Newfoundland, 1997.

[21] R.E. Stake, "Program evaluation: particularly program evaluation," in Evaluation models: viewpoints on educational and human services evaluation, G.F. Madaus, M.S. Scriven, and D.L. Stufflebeam, Eds., Boston: Kluwer-Nijhoff Publishing, 1993.

[22] M. Parlett and D. Hamilton, Evaluation as Illumination: A New Approach to the Study of Innovation Programmes. Edinburg: SCRS, 1972.

[23] M. Parlett and D. Hamilton, "Evaluation as illumination," in Curriculum evaluation today: Trends and implications, D. Tawney, Ed., London: SCRS, 1976.

[24] R.B. Basson, "Evaluation research in education-developments in qualitative approaches," Journal of Education as Change, vol. 10, no. 1, pp. 55-70, 2006.

[25] A. Deligianni, "A responsive and illuminative approach to evaluation of innovatory, foreign language programs," in GALA 14th Conference, 2007.

[26] J. Alcroft, "Illuminative evaluation for design educators using critical trialling," in Conference of the Architectureal Education Exchange, pp.1-3, 2012.

[27] L. Alderman, "Illuminative evaluation as a method applied to Australian Government policy borrowing and implementation in higher education," Evaluation Journal of Australasia, vol. 15, no. 1, pp. 4-14, 2015.

[28] J. Carter, "Listening to the voices of children: an illuminative evaluation of the teaching of early reading in the light of the phonics screening check," Literacy, vol. 54, no. 1, pp. 49-57, 2020.

[29] G.W. Chirwa, "An illuminative evaluation of the standard expressive arts curriculum in Malawi," Ph.D. dissertation, University of the Witwatersrand, Johannesburg, 2010.

[30] L.N. Ellis and M. Nolan, "Illuminating continuing professional education: Unpacking the black box," International Journal of Nursing Studies, vol. 42, no. 1, pp. 97-106, 2005.

[31] J.K. Garwood, "Identification of specific learning disability in New Jersey: An illuminative evaluation," M.A. Thesis Dissertations, Rowan University, 2015.

[32] R. Hanson, "The impact of two-tier instruments on undergraduate chemistry teacher trainees: An illuminative assessment," International Journal for Infonomics, vol. 12, no. 4, pp. 1920-1928, 2019.

[33] I. Lowe, "Policy and practice in the teaching of mathematics education in the rural primary schools in Malawi," Ph.D. dissertation, Monash University, Melbourne, 2008.

[34] M.C. Mannathoko and A. Mamvuto, "Learner involvement in art and design education assessment: The missing matrix in Botswana's primary schools," Arts Education Policy Review, vol. 119. no. 3, pp. 172-184, 2017.

[35] M.C. Mannathoko and T.E. Major, "An illuminative evaluation on practical art, craft and design instruction: The case of Botswana," International Journal of Higher Education, vol. 2, no. 3, pp. 54-61, 2013.

[36] W. R. Miles, "Illuminative evaluation for formative decision-making: A case study of teaching/learning styles," Education Review, vol. 4, no. 4, pp. 79-99, 1981.

[37] F. Özüdoğru and O.C. Adıgüzel, "The Analysis of the views of English teachers about 2nd grade English language teaching curriculum," e-International Journal of Educational Research, vol. 7, no. 2, pp. 16-35, 2016.

[38] G. Sloan and H. Watson, "Illuminative evaluation: Evaluating clinical supervision on its performance rather than the applause," Journal of Advanced Nursing, vol. 35, no. 5, pp. 664-673, 2001.

[39] P. Smith, A. Masterson, and S. Lask, "Health and the curriculum: An illuminative evaluation," Nurse Education Today, vol. 15, no. 4, pp. 245-249, 1995.

[40] S. Soeprijanto and G. Femalia. "Evaluation of nature school in Indonesia using illuminative evaluation model," in The 9th International Conference on Global Resource Conservation, pp. 1-8, 2019.

[41] A. Topper and S. Lancaster. "Online graduate educational technology program: An illuminative evaluation," Studies in Educational Evaluation, vol. 51, pp. 108-115, December 2016.

[42] E. Van Rensburg, "Evaluating work-based learning: insights from an illuminative evaluation study of work-based learning in a vocational qualification," Industry and Higher Education, vol. 22, no. 4, pp. 223-232, 2008.

[43] Y. Yang. "Evaluation of a curriculum," in 2nd International Conference on Contemporary Education, Social Sciences and Humanities, pp. 180-183, 2017.

[44] Y. Ying and T. Mursitama, "Illuminative approach in evaluation of curriculum of Chinese Literature Department," Journal of Computational and Theoretical Nanoscience, vol. 23, no. 4, pp. 3064-3067, 2017.

[45] S. Yoon, M.Y. Park, and M. McMillan, "An illuminative evaluation: Student experience of Qipped learning using online contents," Journal of Problem-Based Learning, vol. 4, no. 1, pp. 47-54, 2017.

[46] J. Mcmillan, Educational research fundamental for the consumer. Boston: Pearson Education, 2008.

[47] L. W. Suen, H. Huang and H. Lee, "A comparison of convenience sampling and purposive sampling," $\mathrm{Hu} \mathrm{Li} \mathrm{Za}$ Zhi, vol. 61, no. 3, pp. 105-111, 2014. 
[48] D.S. Moore and G.P. McCabe, Introduction to the Practice of Statistics, 5th ed. New York: W.H. Freeman and Company, 2005.

[49] L. Braskamp, "On being responsive and responsible," The CHEA Chronicle, vol. 1, no. 6, 1998. [Online]. Available: https://www.chea.org/being-responsive-and-responsible

[50] R. Schoenfeld-Tacher and H.J. Baker, "Educational theory and practice," Journal of Veterniary Education, vol. 40, no. 2, pp. 94-95, 2013.

[51] D. Ekong and N. Cloete, "Curriculum responses to a changing national and global environment in an African context," in Knowledge, Identity and Curriculum Transformation in South Africa, N. Cloete, J. Muller, M.W. Makgoba and D. Ekong, Eds. Maskew Miller Longman: Cape Town, 1997.

[52] A. Smith and F. Webster, "Changing ideas of the university," in The Postmodern University? Contested Visions of Higher Education in Society, A. Smith and F. Webster, Eds. SRHE \& Open University Press: Buckingham, 1997. 